\title{
ANALYSIS AND MODELING OF DYNAMICS OF REVENUES TO THE BUDGETS OF THE UNITED TERRITORIAL COMMUNITIES OF THE ZAPORIZHZHIA REGION
}

\author{
Bashtannik O.I., Polova A.V., Maksyshko N.K. \\ Zaporizhzhia National University \\ Ukraine, 69600, Zaporizhzhia, Zhukovsky str., 66
}

obasht2@gmail.com,polova_alyona@ukr.net,maxishko@ukr.net

ORCID: 0000-0002-0473-7195

Key words:

united territorial community, fractal analysis, local budget, budget revenues, cluster analysis, decentralization
The United Territorial Community (UTC), as an object formed by the voluntary amalgamation of territorial communities within one region, has a single local selfgovernment body endowed with additional powers and budget revenues. Currently, an urgent problem for each UTC is the awareness not only of the amount of budget revenues, but their structure, the nature of the dynamics as a whole and in terms of their types. The UTC revenue planning requires their forecasting, and the use of relevant forecasting tools necessitates the study of the peculiarities of their structure and dynamics. The purpose of this work is to analyze the structure and dynamics of revenues to the budgets of the UTC of Zaporizhzhia region and to develop recommendations to community leaders on the choice of object, models and methods of forecasting revenues. The analysis of the current state of decentralization reform in Zaporizhzhia region has been carried out in the work. The dynamics and structure of revenues to the budgets of the UTC of the Zaporizhzhia region for 2016-2019 have been analyzed. The tendencies of dynamics of formation of incomes of local budgets have been defined. A cluster analysis has been conducted for the budget of Veselivska UTC, on the basis of which it has been found that the revenues are divided into four groups that have similar dynamics. A fractal analysis of receipts has been performed. Based on the analysis, recommendations for the selection of the object, models and methods for revenue forecasting have been developed.

\section{АНАЛІЗ ТА МОДЕЛЮВАННЯ ДИНАМІКИ НАДХОДЖЕНЬ ДО БЮДЖЕТІВ ОБ'ЄДНАНИХ ТЕРИТОРІАЛЬНИХ ГРОМАД ЗАПОРІЗЬКОЇ ОБЛАСТІ}

\author{
Баштанник О.І., Полова А.В., Максишко Н.К. \\ Запорізький наиіонаьний університет \\ Украӥна, 69600, м. Запоріжжя, вул. Жуковського, бб
}

\begin{abstract}
Ключові слова:
об'єднана територіальна громада, фрактальний аналіз, місцевий бюджет, надходження бюджету, кластерний аналіз, децентралізація.
\end{abstract}

Об'єднана територіальна громада (ОТГ) як об'єкт, утворений шляхом добровільного об'єднання територіальних громад в межах однієї області, має єдиний орган місцевого самоврядування, наділений додатковими повноваженнями та бюджетними надходженнями. На даний час актуальною проблемою для кожної ОТГ є усвідомлення не тільки обсягів бюджетних надходжень, але їх структури, характеру динаміки в цілому та у розрізі їх видів. Планування доходів ОТГ потребує їх прогнозування, а застосування релевантного інструментарію прогнозування зумовлює необхідність дослідження особливостей їх структури та динаміки. Метою цієї роботи $є$ аналіз структури та динаміки надходжень до бюджетів ОТГ Запорізької області та розробка рекомендацій керівництву громад щодо вибору об'єкту, моделей та методів прогнозування надходжень. У роботі проведено аналіз сучасного стану реформи децентралізації в Запорізькій області. Проаналізовані динаміка i структура надходжень до бюджетів ОТГ Запорізької області за 2016-2019 роки. Визначено тенденції динаміки формування доходів місцевих бюджетів. Для бюджету Веселівської ОТГ проведено кластерний аналіз, на основі якого виявлено, що надходження розділяються на чотири групи, які мають подібну динаміку. Проведено фрактальний аналіз надходжень. На основі аналізу розроблено рекомендації щодо вибору об'єкту, моделей і методів для прогнозування надходжень.

\section{Statement of the problem}

State policy of Ukraine in the field of local selfgovernment is based on the interests of residents of territorial communities and provides for decentralization of power: the transfer of executive power to local governments a significant part of the powers and, importantly, resources. The UTC as an object formed by voluntary association of territorial communities within one region, has a single local government body, endowed with additional powers and budget revenues. Currently, an urgent problem for each UTC is the awareness not only of the amount of budget revenues, but their structure, the nature of the dynamics as a whole and in 
terms of their types. The UTC revenue planning requires their forecasting, and the use of relevant forecasting tools necessitates the study of the peculiarities of their structure and dynamics.

\section{Analysis of recent studies and publications}

The research on the theoretical aspects of local budgets as the financial basis of the existence of local communities devoted to the works of many Ukrainian scientists, such as V. Andrushchenko [1], S. Bukovynskiy [2], A. Buryachenko [3], A. Kirilenko [4], O Kovalyuk [5], R. Khalkhash [6], M. Kulchytsky [7], V. Oparin [8], Y. Pasichnyk [9] and others.

Despite significant scientific work in the field of local budget research, financial theory does not have a single common definition of the essence of local budgets, which requires further research to establish the economic essence of local budgets and their role in the current budget system of Ukraine.

A number of national scientists have studied the problems of decentralization and the formation, development and reform of local self-government in Ukraine, among which are: O. Batanov [10], T. Baranovska [11], A. Buchynska [12], V. Gladiy [13], N. Kondratska [14], Yu. Pasichnyk [15], P. Lyubchenko [16], S. Seryogin [17], I. Yaroshenko [18], R. Grishko [19], T. Bardina [20] considers the problem of rural development in the context of reform. Among the scientific works devoted to the formation of local budget revenues and their balancing, it is necessary to single out the works of scientists: O. Kyrylenko [21], S. Yuri [22], V. Pogorelov [23].

The insufficient attention is given to the analysis of the structure and dynamics of revenues to the budgets of the UTC. Also remain unresolved following questions: determining the capacity of newly formed communities; assessment of economic development of communities; the impact of the UTC budget revenues on the investment attractiveness of communities.

\section{Objectives of the article}

The objective of this work is to analyze the structure and dynamics of revenues to the budgets of the UTC in the Zaporizhzhia region and develop recommendations to community leaders on the choice of object, models and methods of forecasting revenues.
According to the goal, the tasks were set: to analyze the dynamics of revenues to the budgets of the UTC in the Zaporizhzhia region, its nature, identified trends in the dynamics of local budget revenues; conduct a cluster analysis of the dynamics and fractal analysis of receipts; develop recommendations for the selection of facilities, models and methods for revenue forecasting.

\section{The main material of the research}

In the Zaporizhzhia region, decentralization reform is being actively implemented, which affects the level of financial capacity of administrative-territorial units, changes in relations between state and local budgets.

As of January 2020, there are 61 UTCs operating in Zaporizhzhia region [24], which is $5.7 \%$ of UTC in Ukraine, of which: in 20156 UTCs were formed, since 2016 another 10 UTCs have been operating in the oblast, since 2017 - 20 UTC, in 2018 - 8 UTC, in 2019 - 17 UTC. Thus, $75.67 \%$ of the area of the region and $31.0 \%$ of the population are covered by UTC, formed as a result of reforming the administrative-territorial system.

The availability of expenditures related to the performance of their functions by local authorities determines the need for revenue. Planning of local budget revenues requires an in-depth analysis not only of the level achieved, but also the dynamics of budget revenues. Comparisons can be made both by types of revenues and by subjects of revenues (individuals or legal entities, budgets of lower levels, etc.).

The main objectives of the analysis and modeling are the study of the state of budget revenues; forecasting (forecasting) future revenues; improving the management of revenue sources.

Thus, analysis and forecasting are the basic components of UTC management technology, the basis for a more balanced formation of their budgets.

The first step in analyzing the dynamics of time series is to visualize the behavior of time series by constructing appropriate graphs and charts. Figure 1 shows the dynamics of total revenues to the budgets of the first 6 UTCs of the Zaporizhzhia region for the period from January 2016 to September 2019.

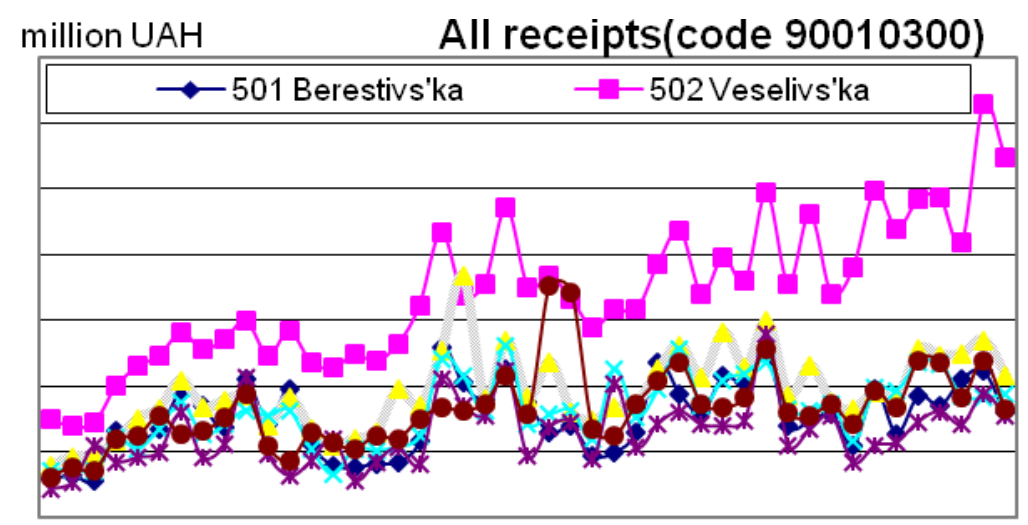

month, year

Fig. 1. Dynamics of monthly total revenues to the budgets of 6 UTCs of the Zaporizhzhia region for the period from January 2016 to September 2019 
Based on the visual analysis of the graphs of Figure 1, it is possible to draw the following preliminary conclusions:

- revenues in the budgets of each community show an increasing trend throughout the period under study;

- significant seasonal fluctuations in revenues are not observed during the study period;

- Veselivka UTC has from 1.8 to 2.6 times higher revenues than other UTCs, due to the excess of the population from 2 to 3.8 times compared to other communities and a large area, so for a practical analysis of aspects of local budget revenues this UTC has been chosen.

Table 1 shows that Veselivska UTC's own revenues are approximately equal to the proceeds from official transfers. Transfers from the State Budget are calculated and received by UTC budgets according to formulas, their amounts mainly depend on the number of UTC residents and their areas.

Table 1 - The volume and growth rate of revenues to the budget of Veselivska UTC in 2016-2018

\begin{tabular}{|c|c|c|c|c|c|c|}
\hline \multirow{3}{*}{$\begin{array}{c}\text { Budget } \\
\text { classification } \\
\text { code }\end{array}$} & \multirow[b]{3}{*}{ Type of income } & \multicolumn{5}{|c|}{ Year } \\
\hline & & \multirow{2}{*}{$\begin{array}{c}2016 \\
\text { Thousand } \\
\text { UAH. }\end{array}$} & \multicolumn{2}{|c|}{2017} & \multicolumn{2}{|c|}{2018} \\
\hline & & & $\begin{array}{c}\text { Thousand } \\
\text { UAH. }\end{array}$ & $\begin{array}{c}\text { Growth rate } \\
\text { compared to } \\
2016, \%\end{array}$ & $\begin{array}{c}\text { Thousand } \\
\text { UAH. }\end{array}$ & $\begin{array}{c}\text { Growth rate } \\
\text { compared to } \\
2017, \%\end{array}$ \\
\hline 10000000 & Tax revenues & 28870,05 & 39738,89 & 137,4 & 45854,83 & 115,4 \\
\hline 20000000 & Non-tax revenues & 1335,66 & 2054,78 & 153,8 & 2754,00 & 134,0 \\
\hline 30000000 & $\begin{array}{c}\text { Income from } \\
\text { capital transactions }\end{array}$ & 0,953 & 3,743 & 392,8 & 13,834 & 369,6 \\
\hline 40000000 & Official transfers & 23909,84 & 33237,64 & 139,0 & 36662,19 & 110,3 \\
\hline \multicolumn{2}{|c|}{ Total ownership of revenues } & 30206,67 & 41797,41 & 138,4 & 48622,67 & 116,3 \\
\hline \multicolumn{2}{|l|}{ Total income } & 54116,50 & 75035,047 & 138,7 & 85284,86 & 113,7 \\
\hline
\end{tabular}

In 2019 , total revenues increased by $25.9 \%$ and amounted to UAH 113 million.

To analyze the dynamics of revenues to the budget of Veselivska UTC, the relevant time series were visualized by constructing graphs and charts. Figure 2 shows the dynamics of total revenues to the budgets of Veselivska UTC for the period from January 2016 to September 2019.

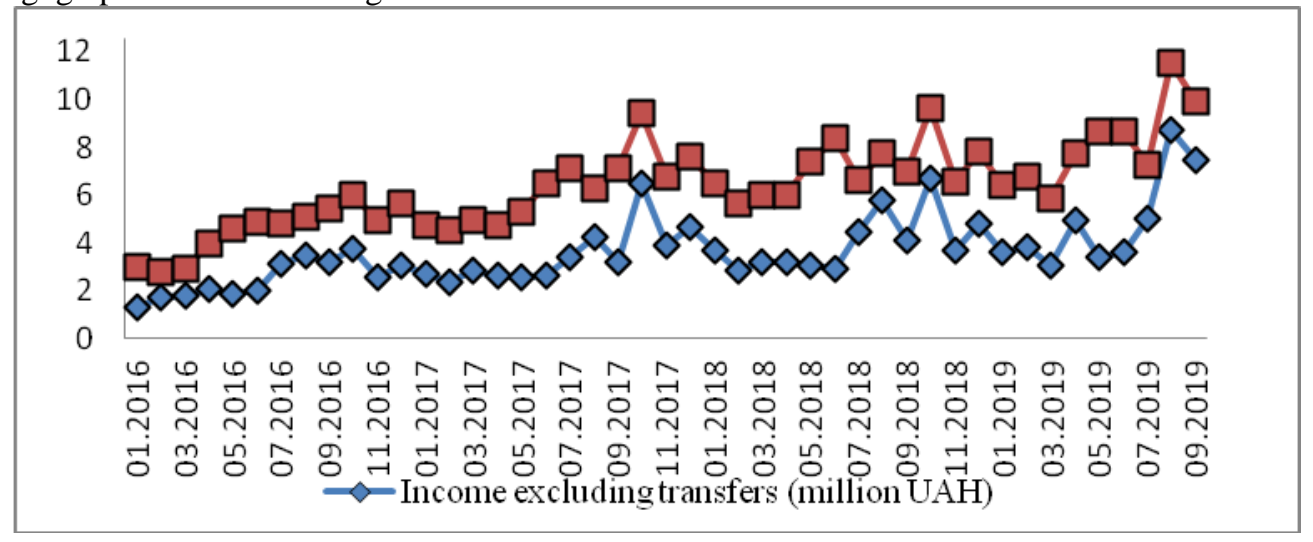

Fig. 2. Dynamics of monthly revenues to the budget of Veselivska UTC in the period from January 2016 to September 2019 enues to the budget of Veselivska UTC in the period from January 2016 to September 2019

Tax revenues of Veselivska UTC consist of the following categories [25]:

- 11000000 - "Personal income tax";

- 13000000 - "Fees for special use of natural resources";

- 14000000 - "Internal taxes on goods and services";
- 18000000 - "Local taxes";

- 19000000 - "Other taxes and fees".

Let's analyze the structure of tax revenues presented in Figure 3. 


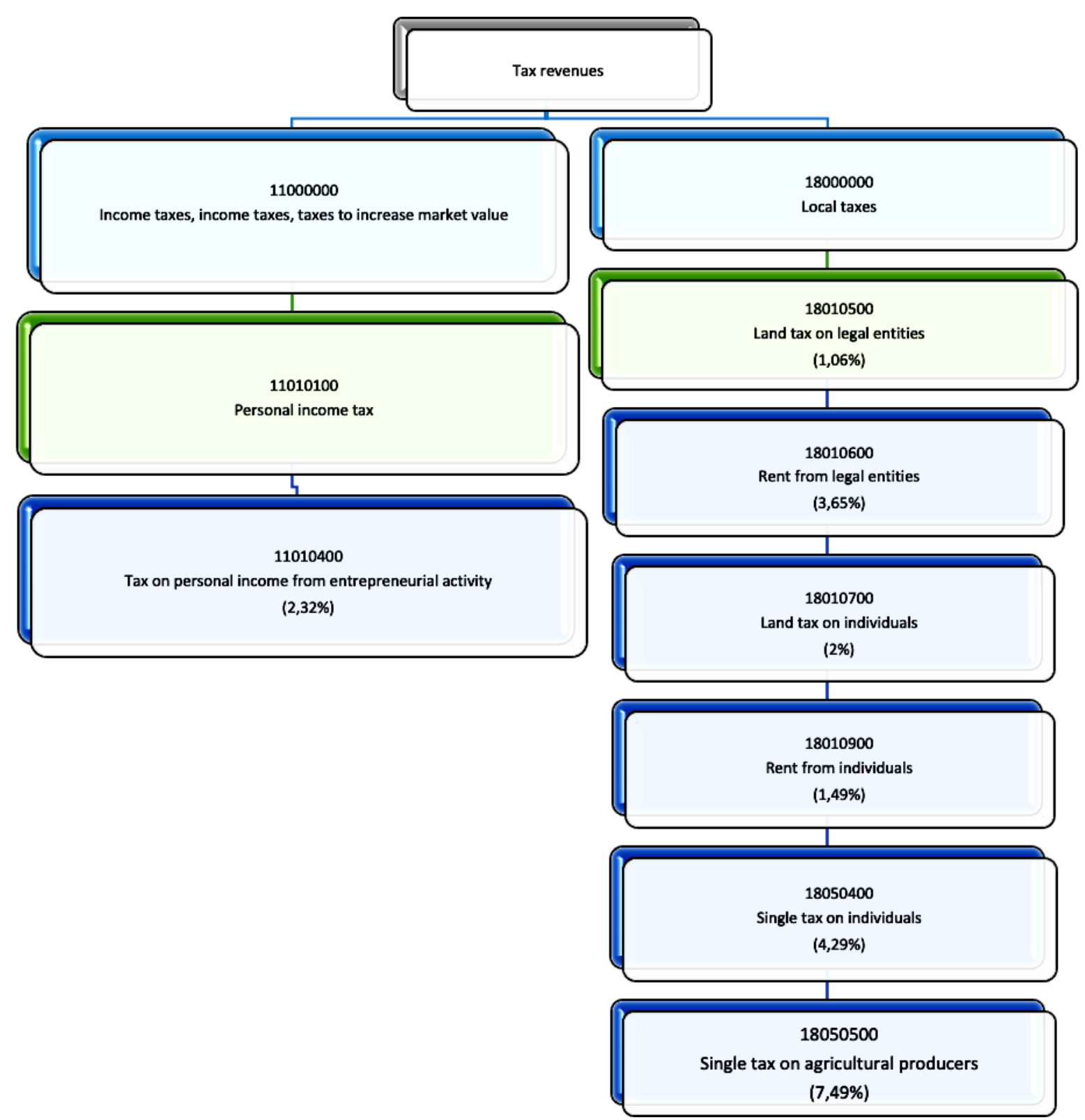

Fig. 3. The structure of tax revenues of Veselivska UTC

The main budget-generating revenue is the personal income tax (PIT), the share in total income of which is $20.43 \%$. The share of local taxes and fees in the structure of budget revenues of Veselivska UTC is $21.37 \%$. Among them are the following taxes: single tax on agricultural producers $(7.49 \%)$; single tax on individuals $(4.29 \%)$; rent from legal entities $(3.65 \%)$; land tax on individuals $(2 \%)$; rent from individuals $(1.49 \%)$; land tax on legal entities $(1.06 \%)$.
Figure 4 shows the changes in the components of tax revenues to the budget of Veselivska UTC in 2016-2019. In different months, the share of different types of revenues changes, but the overall process is more or less stationary. First of all, PIT and local taxes and fees need to be analyzed, and it is also advisable to pay attention to domestic taxes on goods and services (code 14000000). 


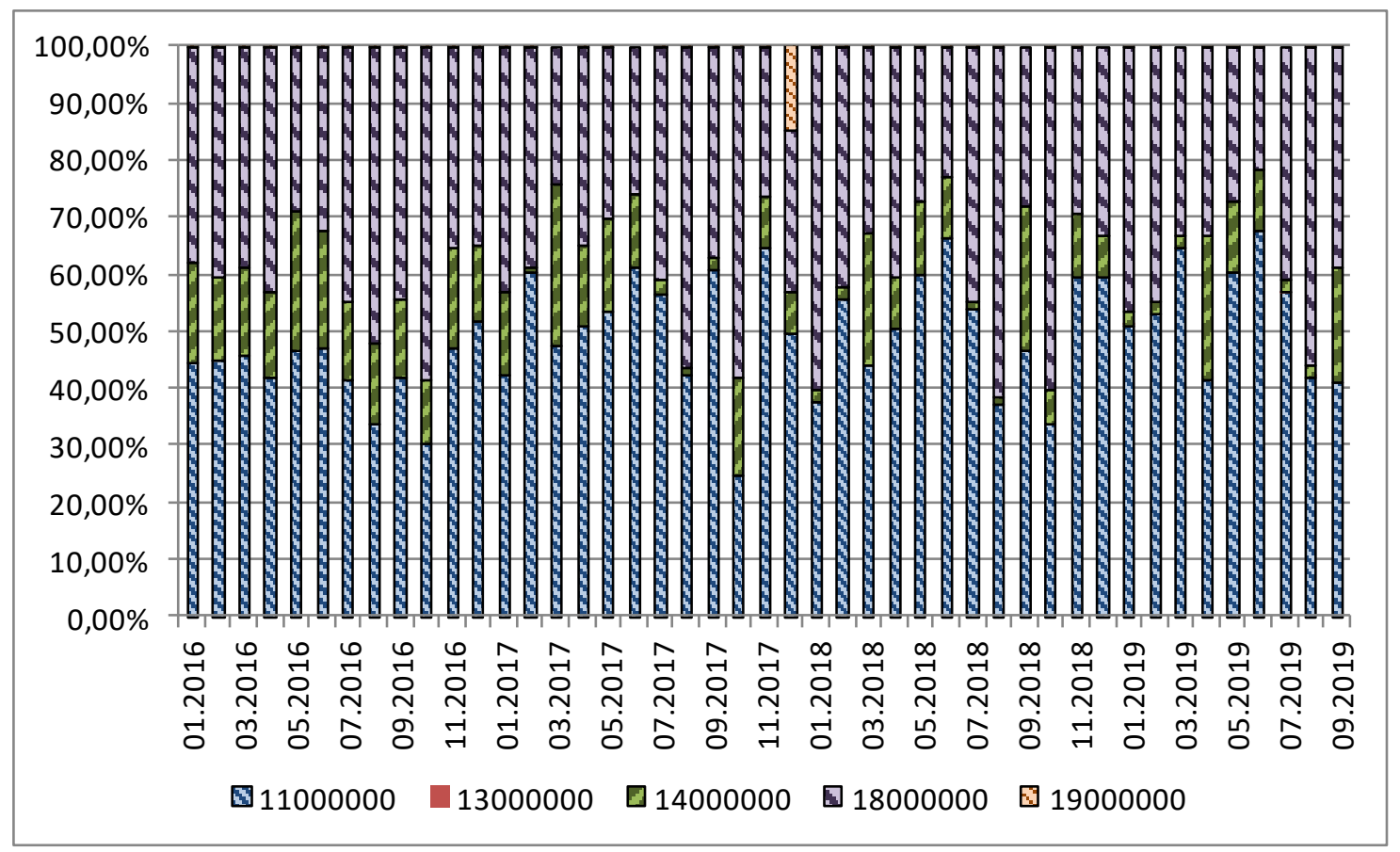

Fig. 4. Changes in the components of monthly tax revenues to the budget of Veselivska UTC for the period from January 2016 to September 2019

\section{Analysis and grouping of revenues by similarity of dynamics}

Let's perform a cluster analysis of revenues to the budget of Veselivska UTC using two methods: PAM method and the Ward's method [26, 27].

The input data for the analysis are monthly data on revenues to the budget of Veselivska UTC for 20162019.

For the cluster analysis, 62 indicators were used - the amount of tax revenues of Veselivska UTC for the period from 2016 to September 2019.
The study used a statistical environment $\mathrm{R}$ [28], which is designed to implement models of Data Mining - a modern direction of in-depth data analysis to identify hidden patterns [29].

As a result of application of the Ward's method, the dendrogram of similarity of taxes (Fig. 5) - a tree of associations of clusters with the specified taxes on a horizontal axis and a scale of distances on a vertical has been received.

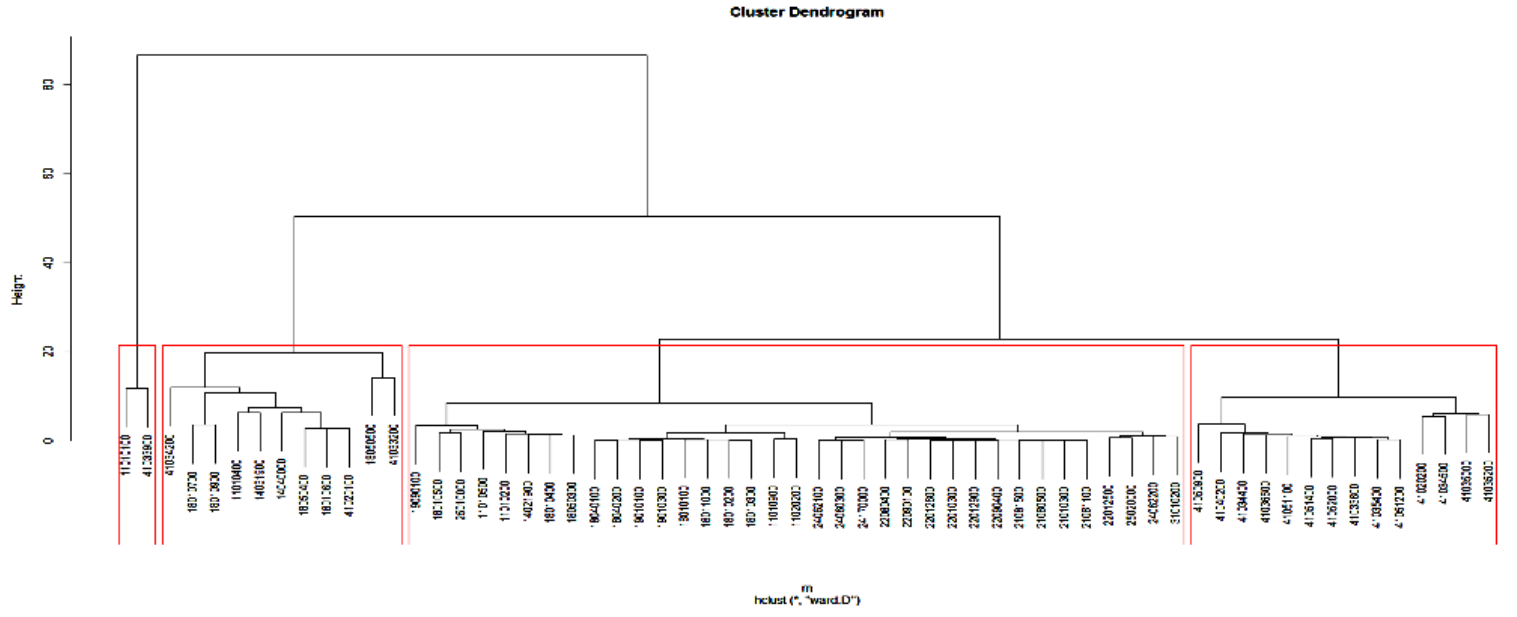

Fig. 5. Dendrogram of tax similarity in dynamics

Let's check the optimality of the number of clusters by the average silhouette width. In fig. 6 for each of the 62 revenue items shows the difference $s$ of the average distances to the objects of its cluster and the third-party cluster closest to the analyzed object. The total average of these values determines the quality of the performed clustering - 0.64 . 


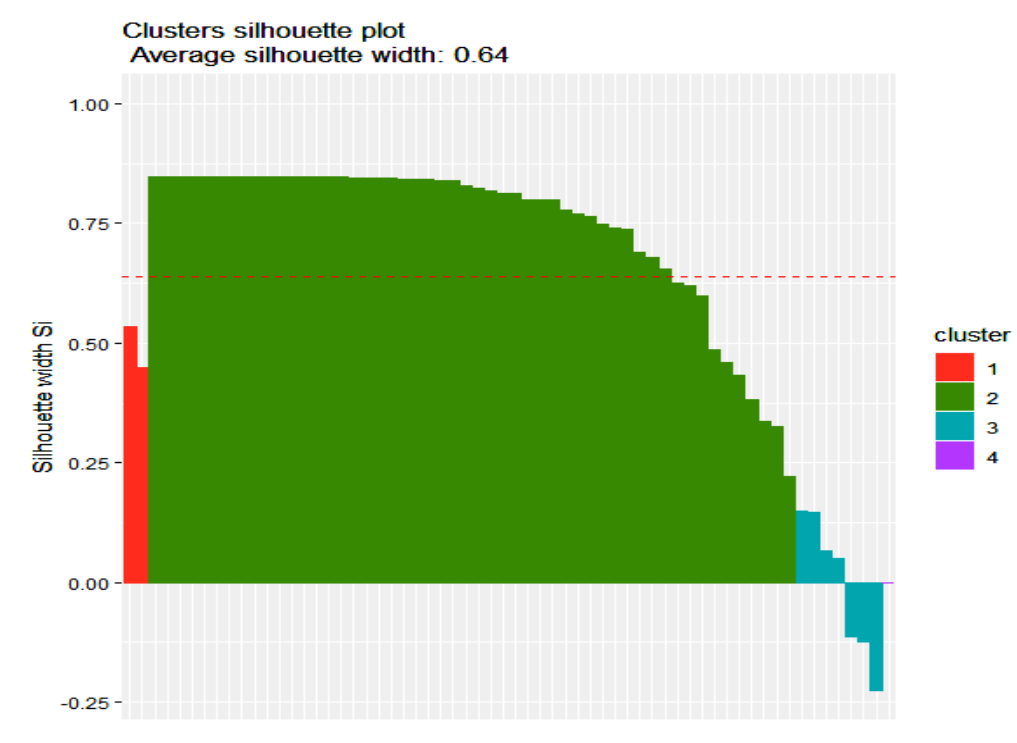

Fig. 6. Diagram of silhouettes when divided into 4 clusters

One of the tasks of cluster analysis is to select the optimal value of the number of clusters. In Fig. 7 presents a graph from which we can make assumptions about the optimal number of clusters: from 4 to 10 .
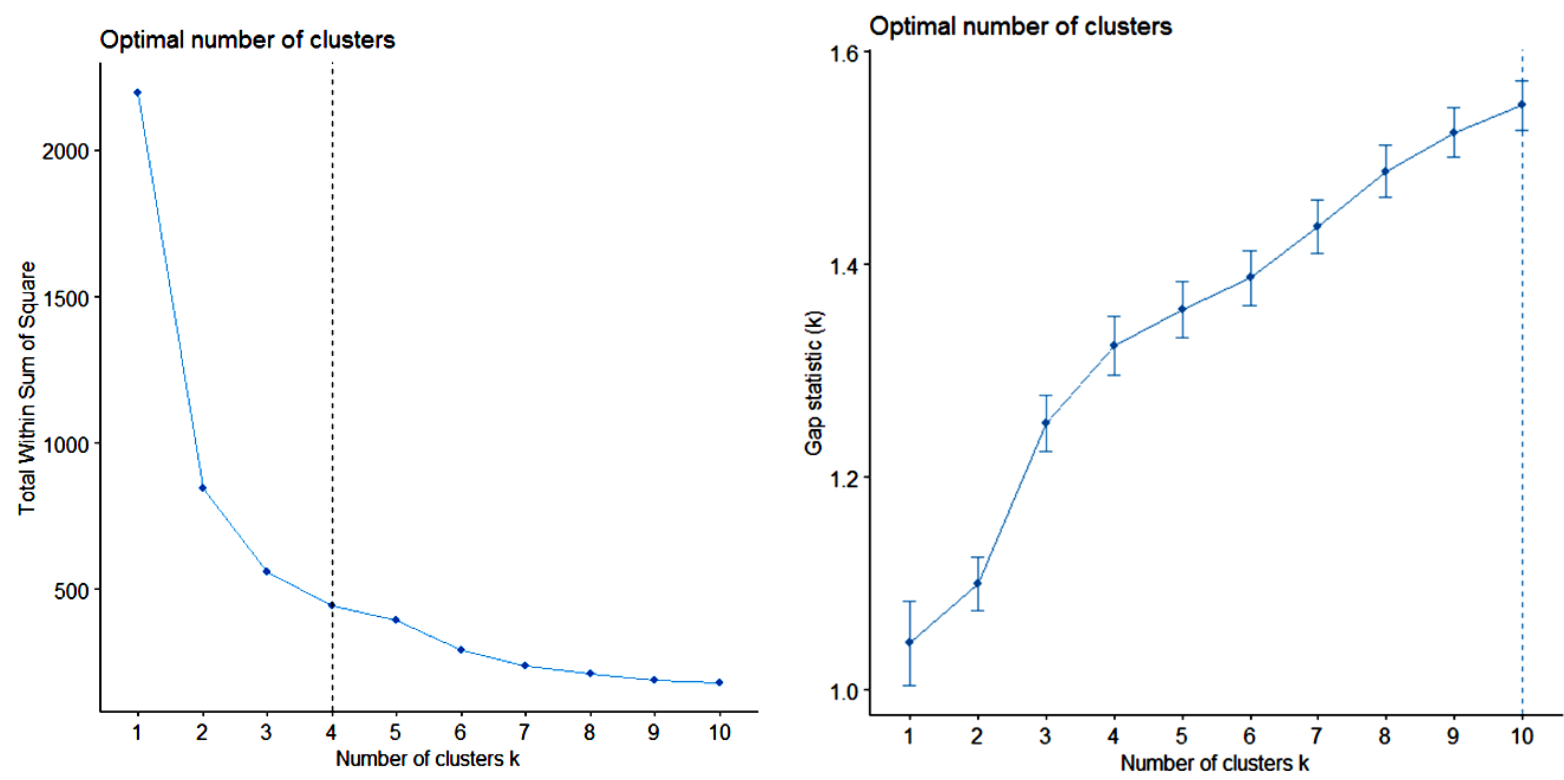

Fig. 7. Selection of the optimal number of clusters by the Elbow method and GAP-statistics

Based on the study, four clusters were identified by the PAM method. The PAM is a modification of the k-mean algorithm, the k-medoids algorithm. The algorithm is less sensitive to noise and data emissions than the k-means algorithm because the medoid is less susceptible to emissions. Instead of calculating centroids, $\mathrm{k}$ is searched for the most representative objects (or medoids) among the analyzed observations. The intracluster scatter is estimated from the Manhattan distance, not the Euclidean distance. The PAM is effective for small databases, but should not be used for large data sets. The results of cluster analysis are presented in Fig. 8.

The first cluster includes the two largest items of income personal income tax (the share in budget revenues is 20\%) and the educational subvention from the state budget (21\%). Together, they form up to $41 \%$ of UTC budget revenues.
The second cluster includes articles with an average impact on budget formation, but with a small share in the budget, together forming $20 \%$ of the budget. Among them are excise tax on fuel, land tax on individuals, rent from individuals, revenues from fees for services provided by budgetary institutions in accordance with the law.

The third cluster includes items of revenue, which form $32 \%$ of the budget. Mainly due to the single tax on agricultural producers, the basic subsidy to the local budget and the medical subvention.

The fourth cluster includes one item of revenues - a subvention from the state budget to local budg 


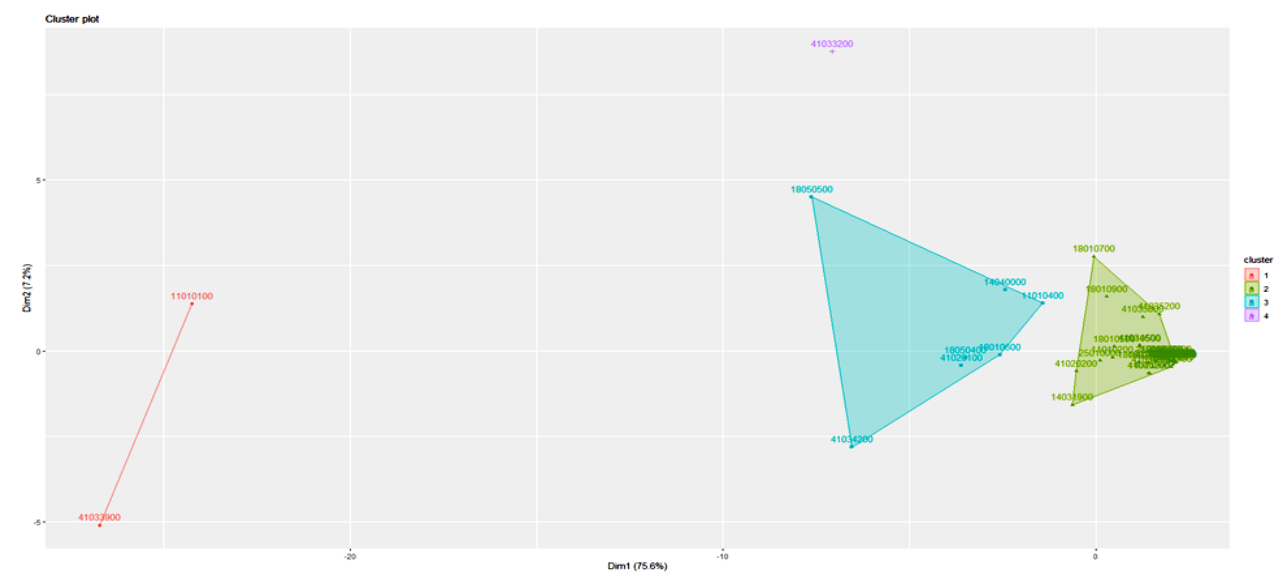

Fig.8. The schedule of distribution of articles of receipts to the budget on clusters

The first cluster includes the two largest items of income - personal income tax (the share in budget revenues is $20 \%$ ) and the educational subvention from the state budget $(21 \%)$. Together, they form up to $41 \%$ of UTC budget revenues.

The second cluster includes articles with an average impact on budget formation, but with a small share in the budget, together forming $20 \%$ of the budget. Among them are excise tax on fuel, land tax on individuals, rent from individuals, revenues from fees for services provided by budgetary institutions in accordance with the law.

The third cluster includes items of revenue, which form $32 \%$ of the budget. Mainly due to the single tax on agricultural producers, the basic subsidy to the local budget and the medical subvention.

The fourth cluster includes one item of revenues - a subvention from the state budget to local budgets for the formation of the UTC infrastructure, which is $7 \%$ of budget revenues.

\section{Analysis of revenue predictability}

The next step is to analyze the depth of memory of time series of budget revenues based on fractal analysis methods. As a result of the analysis, Hurst exponents were determined [30] for selected monthly revenues to Veselivska UTC, which are presented in Table 2.

The presence of the property of persistence (trend resistance) was detected only in the time series of revenues under the code 11010100 (PIT). This means that the time series of such receipts has a long-term memory, and to predict if it is necessary to use methods that take this into account. Other time series of revenues are likely to be random, and it is sufficient to use statistical forecasting methods to predict them.

Table 2 - The value of the Hurst exponent

\begin{tabular}{|l|c|c|}
\hline \multicolumn{1}{|c|}{ Budget classification code } & Hurst exponent, $H$ & $\begin{array}{c}\text { Mixing test, } \\
H_{\text {mepem. }}\end{array}$ \\
\hline 11010100 & 0,86213 & 0,67528 \\
\hline 11010400 & 0,72314 & 0,6361 \\
\hline 18010500 & 0,7343 & 0,71087 \\
\hline 18010600 & 0,61765 & 0,66573 \\
\hline 18010700 & 0,63242 & 0,6097 \\
\hline 18010900 & 0,55359 & 0,62887 \\
\hline 18050500 & 0,6517 & 0,56385 \\
\hline Consolidated receipts & & \\
\hline 10000000 & 0,79694 & 0,54178 \\
\hline 18000000 & 0,72462 & 0,61551 \\
\hline
\end{tabular}

We will conduct a comprehensive fractal analysis for the time series of receipts under the code 11010100. In Fig. 9 presents an example of H-trajectory and R / S-trajectory for the time series of receipts code 11010100 . 


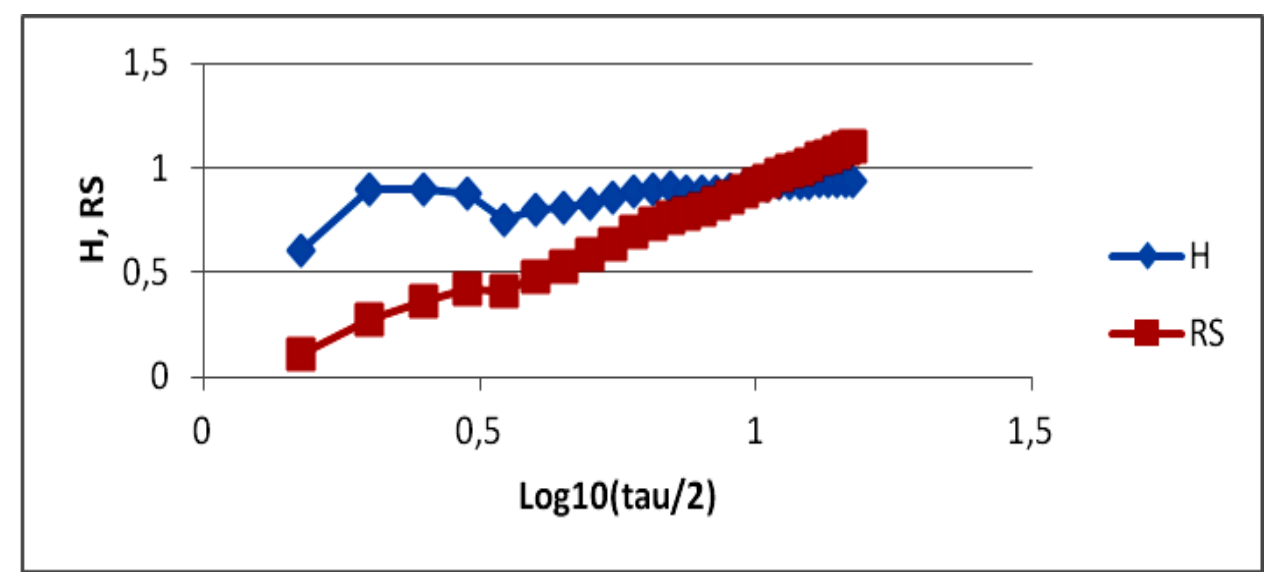

Fig. 9. Example of $H$-trajectory and $\mathrm{R} \backslash \mathrm{S}$-trajectory for the time series of receipts code 11010100

Fig. 9 shows that the breakdown of the trend on the $\mathrm{R} \backslash \mathrm{S}$ -trajectory occurs at the value (on the seventh element of In Fig. 10 constructs a fuzzy set of memory depth of the the trajectory-breakdown, the points on the graph are displayed starting from the third).

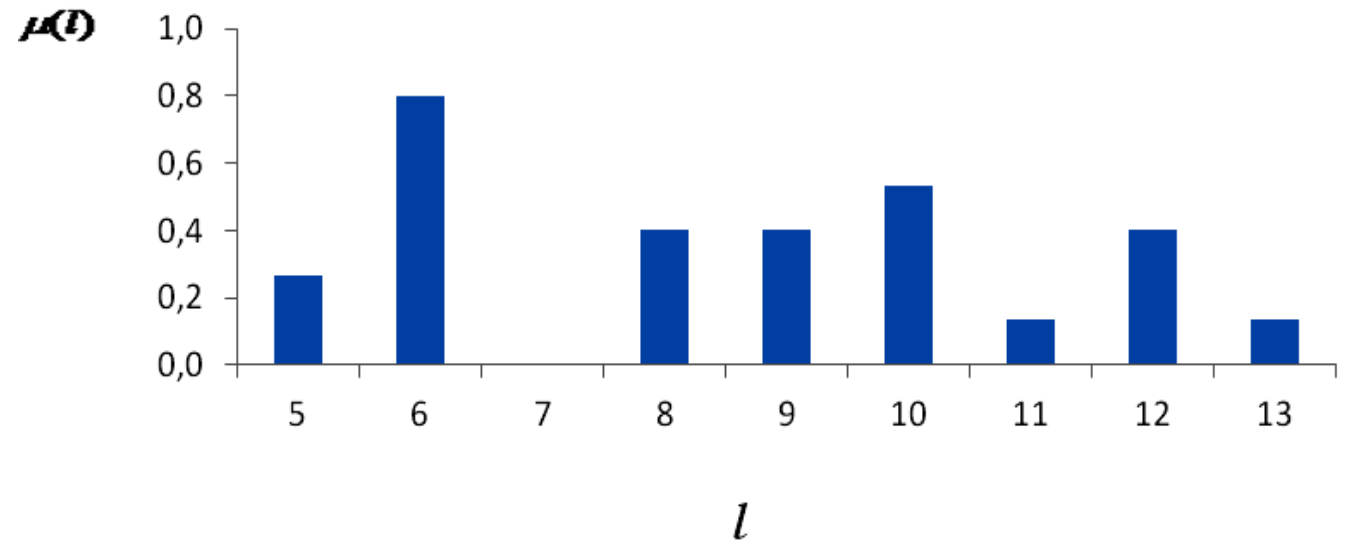

Fig. 10. Fuzzy set $L(X)$ of memory depth of the time series of receipts code 11010100

From Figure 10 we see that the depth of memory, which is most common, is the value - it corresponds to half a year (6 months). However, the center of gravity of the fuzzy set is the value of $1=8.6 \square 9$, i.e. 3 quarters. These parameters can be used to determine the parameters of forecasting models..

The calculation of the Hurst exponent showed that the presence of the property of persistence (trend resistance) was detected only in the time series of revenues under the code 11010100 (PIT). This means that methods that take this into account must be used to predict it. Other time series of revenues are likely to be random, and it is sufficient to use statistical forecasting methods to predict them. The results of complex factor analysis can be used to build forecasting models.

\section{Conclusions}

The analysis of the dynamics and structure of revenues to the budgets of the united territorial communities of the Zaporizhzhia region for 2016-2019 allowed us to conclude that the revenues to the budgets of UTC depend entirely on two factors: favorable geographical location; level of economic development of the community - the location of business structures on its territory.
The analysis of receipts to the budget of Veselivskaya UTC for 2016-2019 is carried out, the detailed analysis of dynamics and structure of own receipts of the specified UTC is carried out. In particular, cluster and fractal analysis were performed.

The structure of own revenues of the budgets of the selected UTCs of the Zaporizhzhia region differs insignificantly. The excess of Veselivska UTC revenues compared to the other five UTCs, which were also established in 2015, is due to the large size of the community and the large population.

According to the results of the analysis of the structure and dynamics of revenues to the budget of Veselivska UTC in the Zaporizhzhia region, the following conclusions can be reached:

the priority task of the community is to create conditions for increasing the welfare of the population by activating the internal potential of the community, modernization of enterprises of the real sector of the economy, further development of acquired and established enterprises; creation of favorable conditions for the development of entrepreneurship, the functioning of institutions and institutions of the social sphere on the basis of innovative 
structural changes; strengthening investment activity and international cooperation; implementation of energy saving measures in the budget sphere;

Veselivska UTC's own revenues are approximately equal to the proceeds from official transfers. The share of official transfers is $42.82 \%$, which is one of the lowest rates among the other 5 oldest UTCs in the Zaporizhzhia region. This is due to a larger amount of own revenues, namely tax, the share of which is more than $50 \%$ in the structure of total community income;

the structure of tax revenues is dominated by personal income tax, the share of which is $44 \%$ (is almost $25 \%$ of total income). That is, it can be argued that personal income tax is the main budget-generating revenue;

the result of clustering was the division of all 62 items of income (own and transferred) into 4 clusters. The first group consists of the main budget-generating revenues personal income tax and education subvention, which together form up to $41 \%$ of budget revenues. The second group includes articles with a medium impact on budgeting. Each individual article forms no more than $1 \%$ of the total community income. The third group includes 7 items of revenue, which have an average impact on the formation of budget revenues due to its own share in total budget revenues (each is from 2 to 4 ). The fourth cluster includes one item of revenues - a subvention from the state budget to local budgets for the formation of UTC infrastructure, which is $7 \%$ of budget revenues and has a weak impact on the formation of UTC budget revenues;

the calculation of the Hurst exponent showed that the presence of the property of persistence (trend resistance) was detected only in the time series of revenues under the code 11010100 (PIT). This means that it is necessary to use methods that take this into account to predict it. Other time series of revenues may be random. The results of complex factor analysis can be used to build forecasting models;

analysis of the main statistics of time series of the following revenues: land tax on individuals, land tax on legal entities, single tax on agricultural producers, rent from individuals, personal income tax from business activities showed that the signs vary greatly and deviate significantly from the law of normal distribution.

\section{References}

1. Andrushchenko, V.L. (2013). Mizhbyudzhetni vidnosyny v Ukrayini i mizhnarodnyy dosvid [Intergovernmental relations in Ukraine and international experience]. Zbirnyk naukovykh prats Irpinskoi finansovo-yurydychnoi akademii (ekonomika, pravo) - Collection of scientific works of Irpin Academy of Finance and Law (economics, law), 2, 5-10 [in Ukrainian].

2. Bukovynskyy, S. (2012). Do pytannya modernizatsiyi derzhavnoho ta mistsevykh byudzhetiv [On the modernization of state and local budgets]. Svit finansiv - The world of finance, 2, 188-193 [in Ukrainian].

3. Buryachenko, A.YE., \& Filimoshkina, I.O. (2018). Fiskalna detsentralizatsiya ta finansova spromozhnist mistsevoho samovryaduvannya $\mathrm{v}$ Ukrayini [Fiscal decentralization and financial capacity of local government in Ukraine]. Finansy Ukrayiny - Finance of Ukraine, 5, 56-68 [in Ukrainian].

4. Kyrylenko, O.P., \& Vatslavskyy, O.I. (2018). Byudzhetnyy kontrol pry planuvanni mistsevykh byudzhetiv [Budget control in planning local budgets]. Svit finansiv - The world of finance, 4, 40-51 [in Ukrainian].

5. Kovalyuk, O.M., \& Danchevska, I.R. (2016). Kharakterystyka orhaniv derzhavnoho finansovoho kontrolyu vykorystannya koshtiv mistsevykh byudzhetiv Ukrayiny [Characteristics of bodies of the state financial control of use of means of local budgets of Ukraine]. Skhidna Yevropa: ekonomika, biznes ta upravlinnya - Eastern Europe: Economy, Business and Management, 2, 272-275 [in Ukrainian].

6. Halhash, R., Semenenko, I., Bilous, YA., \& Burko, IA. (2020). Impact of Decentralization on Sustainable Development of the Newly Created Amalgamated Territorial Communities in the Regions of Ukraine. European Journal of Sustainable Development, 9 (1), 19-33. Retrieved from: DOI: 10.14207/ejsd.2020.v9n1p19 [in Ukrainian].

7. Kulchytskyy, M.I. (2011). Mistsevi byudzhety i mekhanizm yikh formuvannya [Local budgets and the mechanism of their formation]. Finansy Ukrayiny - Finance of Ukraine, 9, 99-102 [in Ukrainian].

8. Oparin, V.M., \& Piontko, N.B. (2017). Derzhavnyy fond rehionalnoho rozvytku v systemi finansovoho vyrivnyuvannya [State Fund for Regional Development in the system of financial equalization]. Finansy Ukrayiny Finance of Ukraine, 7, 25-42 [in Ukrainian].

9. Pasichnyk, YU.V. (2018). Teoretyko-metodolohichne obgruntuvannya rozvytku mistsevykh byudzhetiv v umovakh detsentralizatsiyi [Theoretical and methodological justification for the development of local budgets in terms of decentralization]. Problemy ekonomiky - Problems of the economy, 4, 264-270 [in Ukrainian].

10. Batanov, O.V., \& Kravchenko, V.V. (2018). Mistseve samovryaduvannya yak instytut hromadyans'koho suspil'stva: munitsypalno-pravovi problemy vzayemodiyi ta funktsionuvannya [Local self-government as an institution of civil society: municipal and legal problems of interaction and functioning]. Aspekty publichnoho upravlinnya - Aspects of public administration, 6-7, 45-53 [in Ukrainian].

11. Baranovska, T.M. (2015). Detsentralizatsiya vlady yak osnovnyy napryam vdoskonalennya derzhavnoyi polityky rozvytku terytorialnoyi hromady [Decentralization of power as the main direction of improving the state policy of territorial community development]. Aktualni problemy derzhavnoho upravlinnya - Actual problems of public administration, 2, 145-153 [in Ukrainian]. 
12. Buchynska, A.Y. (2013). Formy publichnoyi diyalnosti orhaniv mistsevoho samovryaduvannya Polshchi ta Ukrayiny: porivnyalnyy analiz [Forms of public activity of local governments of Poland and Ukraine: a comparative analysis]. Visnyk Zaporiz'koho natsionalnoho universytetu. Yurydychni nauky - Bulletin of Zaporizhzhia National University. Legal sciences, 1(2), 69-76 [in Ukrainian].

13. Hladiy, V.I. (2015). Reformuvannya systemy mistsevoho samovryaduvannya: dosvid Vyshehradskoyi hrupy. [Reforming the system of local self-government: the experience of the Visegrad Group]. Hrani - Faces, 12(1), 57-63 [in Ukrainian].

14. Kondratska N. M. (2015). Suchasna systemno-strukturna orhanizatsiya mistsevoho samovryaduvannya v Ukrayini [Modern system-structural organization of local self-government in Ukraine]. Naukovyy visnyk Uzhhorodskoho natsionalnoho universytetu. Seriya. Pravo - Scientific Bulletin of Uzhhorod National University. Series. Law, 35(2.1), 91-96 [in Ukrainian].

15. Pasichnyk, YU.V. (2019). The impact of public debt on economic growth in the countries of the Visegrad group. Ekonomichnyy visnyk. Seriya : Finansy, oblik, opodatkuvannya - Economic Bulletin. Series: Finance, accounting, taxation, 3, 189-203 [in Ukrainian].

16. Lyubchenko, P.M. (2015). Zarubizhnyy dosvid orhanizatsiyi kontrolyu u sferi mistsevoho samovryaduvannya [Foreign experience of control in the field of local government]. Derzhavne budivnytstvo ta mistseve samovryaduvannya - State building and local self-government, 29, 18-31 [in Ukrainian].

17. Serohin, S.S. (2016). Reformuvannya mistsevykh finansiv v umovakh yevrointehratsiyi [Reforming local finances in terms of European integration]. Aspekty publichnoho upravlinnya - Aspects of public administration, 4-5, 87-96 [in Ukrainian].

18. Yaroshenko, I.V. (2015). Problemni pytannya realizatsiyi reformy detsentralizatsiyi vlady v Ukrayini [Problematic issues of implementation of the decentralization reform in Ukraine]. Problemy ekonomiky - Problems of the economy, 4, 177-187 [in Ukrainian].

19. Hryshko, R.YU. (2016). Istoriya transformatsiynykh peretvoren' ukrayinskoyi modeli samovryaduvannya [History of transformational transformations of the Ukrainian model of self-government]. Pravo ta derzhavne upravlinnya - Law and public administration, 4, 107-112 [in Ukrainian].

20. Bardina, T.O. (2018). Rozvytok silskykh terytoriy v umovakh reformy detsentralizatsiyi [Development of rural areas in terms of decentralization reform]. Exstended abstract of candidate's thesis. Poltava [in Ukrainian].

21. Kyrylenko, O.P., \& Vatslavskyy, O.I. (2018). Byudzhetnyy kontrol pry planuvanni mistsevykh byudzhetiv [Budget control in planning local budgets]. Svit finansiv - The world of finance, 4, 40-51 [in Ukrainian].

22. Yuriy, S.M. (2016). Teoretychni zasady mistsevoho samovryaduvannya: zakonodavche vyznachennya ta perspektyvy rozvytku [Theoretical principles of local government: legislative definition and prospects for development]. Naukovyy visnyk Mizhnarodnoho humanitarnoho universytetu. Seriya. Ekonomika i menedzhment - Scientific Bulletin of the International Humanities University. Series. Economics and management, 18, 145-148 [in Ukrainian].

23. Pohoryelov, V.S. (2017). Orhanizatsiya mizhbyudzhetnykh vidnosyn v umovakh fiskalnoyi detsentralizatsiyi [Organization of intergovernmental relations in terms of fiscal decentralization]. Ekonomika Ukrayiny - Ukraine economy, 7, 64-73 [in Ukrainian].

24. Ofitsiynyy sayt Detsentralizatsiyi vlady [Official site of Decentralization of Power]. decentralization.gov.ua. Retrieved from https://decentralization.gov.ua [in Ukrainian].

25. Pro byudzhetnu klasyfikatsiyu: nakaz Ministerstva finansiv Ukrayiny vid 14 sichnya 2011 r. № 11 [On budget classification: order of the Ministry of Finance of Ukraine of January 14, 2011 № 11]. zakon.rada.gov.ua. Retrieved from https://zakon.rada.gov.ua/rada/show/v0011201-11/paran25 [in Ukrainian].

26. Shitikov, V.K., \& Mastitsky, S.E. (2017) Klassifikatsiya, regressiya, algoritmy Data Mining s ispolzovaniyem R [Classification, regression, algorithms Data Mining using R]. github.com/ranalytics/data-mining. Retrieved from https://github.com/ranalytics/data-mining [in Ukrainian].

27. Dudar, O.I., \& Maksyshko, N.K. (2019). Klasternyy analiz podatkovykh nadkhodzhen Veselivskoyi OTH Zaporizkoyi oblasti [Cluster analysis of tax revenues Veselivska UTC Zaporizhzhia region]. Proceedings from Vyklyky ta perspektyvy rozvytku novoyi ekonomiky na svitovomu, derzhavnomu ta rehional'nomu rivnyakh: zbirnyk materialiv XIV Mizhnarodnoyi naukovo-praktichnoyi konferentsiyi - Challenges and prospects for the development of the new economy at the global, state and regional levels: a collection of materials of the XIV International Scientific and Practical Conference. (pp. 287-290). Zaporizhzhia: ZNU [in Ukrainian]

28. Ofitsiyna storinka proyektu R [Official page of the project R]. r-project.org. Retrieved from http://www.r-project.org [in Ukrainian].

29. Fabus, M., Dubrovina, N., Guryanova, L., Chernova, N., \& Zyma, O. (2019). Strengthening financial decentralization: driver or risk factor for sustainable socio-economic development of territories. Entrepreneurship and Sustainability. Issues 7(2). P. 875-890. Retrieved from https://doi.org/10.9770/jesi.2019.7.2(6).

30. Maksyshko, N.K. (2009). Modelyuvannya ekonomiky metodamy dyskretnoyi neliniynoyi dynamiky [Modeling of economy by methods of discrete nonlinear dynamics]. Zaporizhzhia: Polygraph [in Ukrainian]. 